\title{
Applying Kriging algorithm based on Matlab environment to interpolate porosity and permeability values of lower Miocene sandstone reservoir, ST Xam oil field
}

- $\quad$ Thanh Truong Quoc

- $\quad$ Ngoc Thai Ba

- Kha Nguyen Xuan

- Huy Nguyen Xuan

- Ngo Dau Van

- Xuan Tran Van

- Dong Nguyen Duc

- Tuan Nguyen Van

University of Technology, VNU-HCM- tvxuan@hcmut.edu.vn

(Manuscript Received on August 22 ${ }^{\text {th }}, 2014$; Manuscript Revised November 11 $1^{\text {th }}, 2014$ )

\section{ABSTRACT:}

The paper presents the Kriging technique based on Matlab environment applied to interpolate the value of all points in the interpolation range from porosity values obtained from 13 wells of lower Miocene reservoir, ST Xam oil field. The MATLAB function meshgrids are used to create the interpolated cell (cell-Kriging) instead of point discrete interpolation. After selecting the Variogram model with nugget values and the correlation threshold (in scope), the next step is Kriging porosity values which regression permeability values. Finally, displays the values in the cells and interpolated coordinates $X, Y$, respectively. With input data the first mission is to analyze this set, select the necessary parameters and removal of useless data, and assess the scope of application of each type of data. Then

Key words: Kriging, Co- Kriging, MATLAB, Variogram, interpolation, algorithm, porosity and permeability model, recurring.

\section{INTRODUCTION}

General information to lower Miocene sandstone reservoir, ST Xam oil field combine the document with wellogging interpretation results to determine reservoirs and the layered in which filter out the corresponding data averaging and conducting. Based on the selected average value of the corresponding products in each well for each subclass, calculate the results of an empirical Variogram model as the basis for Kriging weighted matrix. The last work is to calculate error and evaluate the reliability of the Kriging results. The error of porosity model are minor and distributed apropriately with kriging range. However the results are numerous correlation. The permeability experiment results are collected just from 03 points, therefore the ultimate solution is recurred porosity from porosity Kriging results.

The Cuu Long basin is an Early Tertiary rift basin located off the southeast coast of Vietnam. The basin extends over Block 01, 02, 15-1, 15-2, 09-1, 09-2, 09-3, 16 and 17 and covers an area of approximately 56,000

\section{Trang 56}


$\mathrm{km}^{2}$. ST Xam Field locates on Block 15-1, North Northeast of Cuu Long Basin in Vietnam continental shelf. Block 15.1 spread over an area of $4,600 \mathrm{~km}^{2}$ (Figure 01). On the basis of the assessment made of geological data, geophysical and these results allow commercial discovery announced May 8/2001 ST Xam Field.

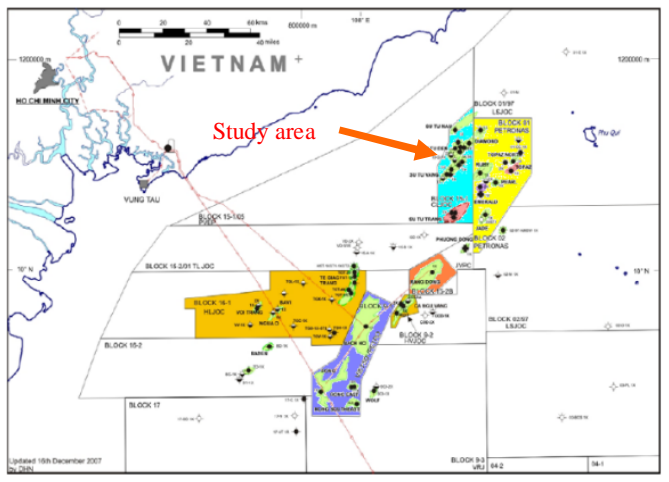

Figure 1: The Location of ST Xam Field

Stratigraphy of ST Xam oil field includes formations from Quaternary sediments to the preTertiary basement rocks among them geology characteristics, paleontologists, sedimentary environment, the oil and gas potential are illustrates in Figure 02.

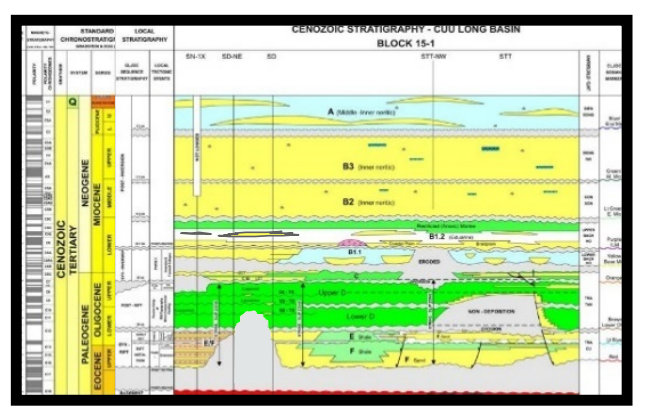

Figure 2: The Stratigraphic column of ST Xam oil Field.

Early Miocene Bach Ho Formation/ "B 1" Sequence distributes from $1650 \div 1750 \mathrm{mSS}$ to $2080-2110 \mathrm{mSS}$ approximately which thickness varies from $410-440 \mathrm{~m}$ to $490 \mathrm{~m}$ respectively.

The "B1" Sequence consists of interbedded sandstone, siltstone, shalestone and divided into two sections: Upper Bach Ho extends down to Intra Lower Miocene Unconformity and Lower Bach Ho extends to the top sequence $\mathrm{C}$.
Upper Bach Ho Formation: The Upper Bach Ho consists of the Rotalia Bed (Bach Ho Shale) on topmost part with predominantly shalestone and the lower part with interbedded shalestone, sandstone and siltstone.

Lower Bach Ho Formation: The Lower Bach Ho formation from Intra Lower Miocene Unconformity to top Sequence C consists of interbedded sandstone, siltstone and shalestone.

The uncertainty during interpolate porosity and permeability of clastic reservoir

Uncertainty quantification is an increasingly important aspect of many areas of computational science. Weather forecasting, global climate modelling, complex engineering designs such as aircraft systems, all porosity and permeability have needs to make reliable prediction and these predictions frequently depend on features that are hard to model at the required level of detail [6].

The properties of reservoir, and specifically prediction of uncertainty in major physical properties oil reservoirs, is another area where accurate quantification of uncertainties in predictions is important because of the critical decision made. In the oil industry, predictions the porosity and permeability of oil reservoirs are difficult to make with confidence because, although the reservoir properties can be determined with reasonable accuracy, the fluid flow is controlled by the unknown rock permeability and porosity. The rock properties can be measured by taking samples at wells, but this represents only a tiny fraction of the total reservoir volume, leading to significant uncertainties in porosity and permeability predictions.

Predicting porosity and permeability of oil and gas reservoirs is a challenging problem. The reservoir rocks tend to be a complex mixture of many components, with experimentally determined core properties and other approaches are likely to be heterogeneity.

The major source of uncertainty for all major physical properties is lack of knowledge of the formation properties. The fluids flow through a porous matrix whose porosity (ability to store fluid) and permeability (resistance to flow) are unknown [5]. Both porosity and permeability vary across the reservoir, with variations determined by the geological processes that 
deposited the reservoir and subsequent processes such as deposition and cementation of the rock grains. The most direct way to measure porosity and permeability is to take a core sample while drilling a well - usually around a 3 in. length of rock whose properties are measured in the laboratory [7]. This means that the sampling for these fundamental properties that can vary dramatically across a reservoir is very limited. It is also possible to use indirect methods such as logging, interpolation which sample a greater, although still extremely limited volume.

In fundamentally, there are several interpolation techniques, such as: Nearest Neighbour, Moving Average, Inverse Distance, Kriging.

Based on the interpolation purposes (to predict the distribution of porosity and permeability) and available data, in this research the Kriging technique is chosen to interpolate.

General procedure for interpolating the porosity and permeability values of Lower Miocene sandstone reservoir, ST Xam oil field as follows: Select data points (control points-the well) surrounding the point at which you want an estimate and then estimate unknown point as a weighted linear combination of surrounding data.

\section{The objective application and data base}

The Kriging interpolation applied for top (A layer) of Lower Miocene formation, ST Xam oil field; The data base for Kriging interpolation of porosity and permeability values icluding here after:

The wellog data: supplying the variation of porosiry by depth. The wellog intepretation data: supplying the data to recognize the reservoir and their zonation. The core analysis data: supplying the porosity and permeability values and their relationships (in clastic reservoir only).

\section{The Kriging interpolation colaborating with Matlab}

Based on input data, the first mission is analyzing data, filtering the request set, and get out the useless data, assess the application scope of each data type. Afterwards synthesis the data with wellog interpretation data in order to determine the potential reservoir and their layers, filtering and dividing in to aproriate zone, at last take normalization.
Form average value of separate layer in each well, calculating to determine: the experiment Variogram model which will be used as fundamental for Kriging weighted matrix.

The last target is calculated the error and assess the certainty range of Kriging results.

The work flow is summerized in (Figure 03).

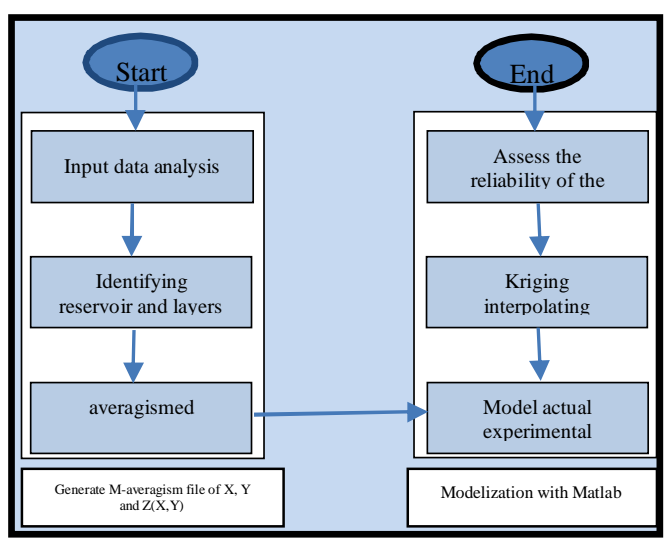

Figure 3: The work flow of Kriging combine with Matlab

\section{Analyzing and preparing the input data}

a) Reservoir data filtering with depth

The wellog interpretation results of lower Miocene reservoir, ST Xam oil field indicated there are abudant 04 sandy layers: A, C, E, G with intersected by thin shale layers (figure 04) [1]. Therefore the interpolative Kriging need to appropriate with data of each layer. The dividing and filtering of layers are description in (Figure 04, 05 and 06);

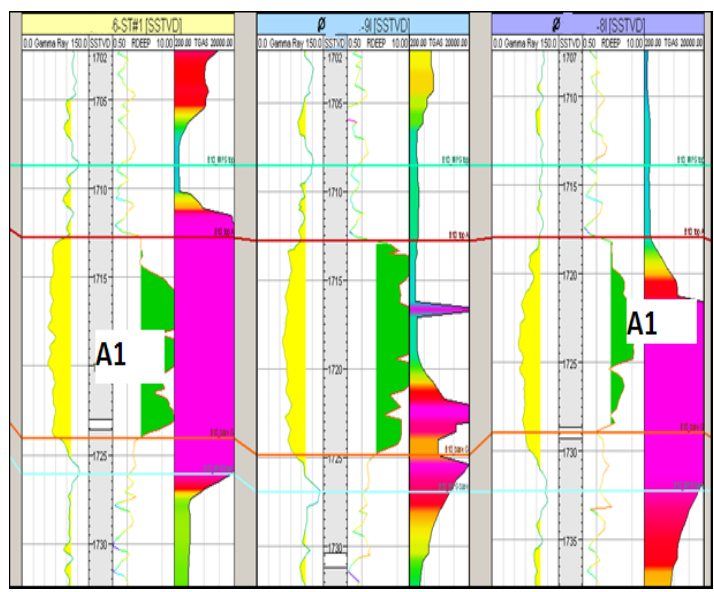

Figure 4: Wellog interpretation data of Lower Miocene reservoir

\section{Trang 58}




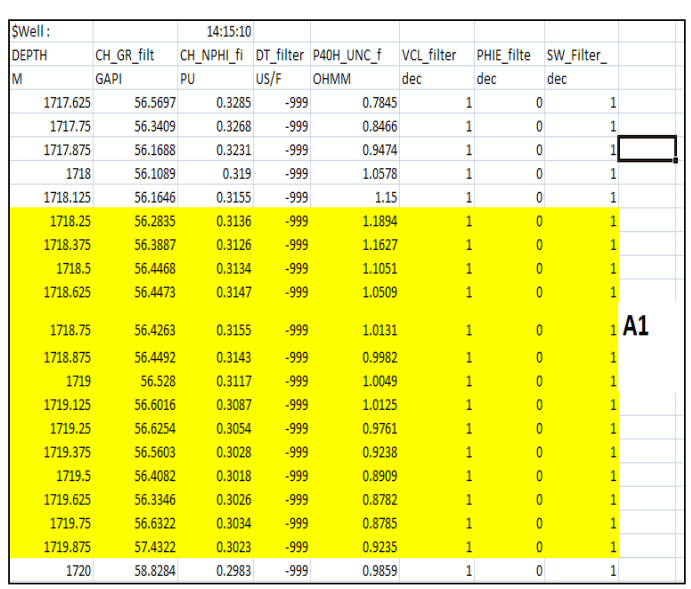

Figure 5: Determine the data set appropriated with lower Miocene reservoir

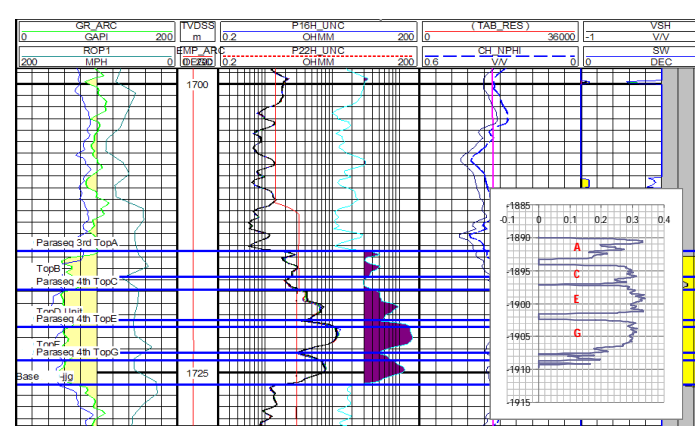

Figure 6: The porosity appropriated with layers in A1 reservoir

b) Build up the histogram for data set of A1 strata and A layer (Figure 07)

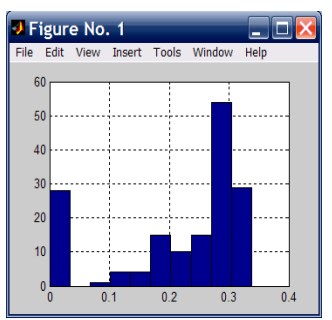

(a)

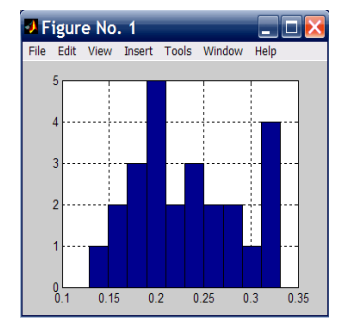

(b)
Figure 7: Porosity histogram of A1 strata (a) and A layer (b)

c) The porosity-permeability relationship by core analysis.

Based on the core analysis results, primary relationship between porosities and permeability are determined here after: $\log (\mathrm{K})=23.34086$.PHI 3.477972 (Figure 08).
THE GRAPH OF POROSITY-PERMEABILITY RELATIONSHIP BY CORE DATA

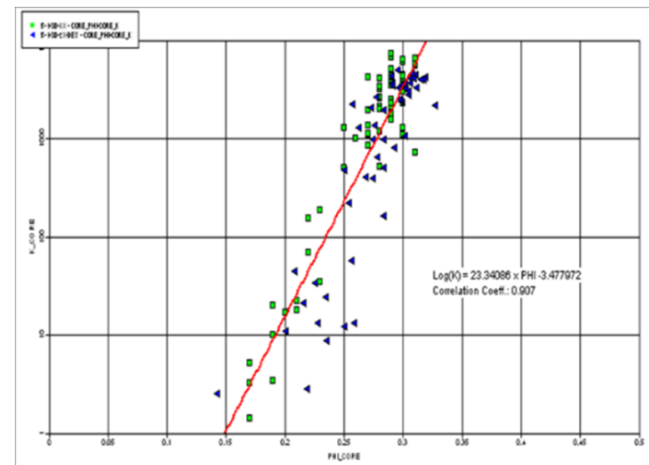

d) The porosity and permeability normalization by layers

\begin{tabular}{|c|c|c|}
\hline Well & Phi & K \\
\hline 1A & 0.201494 & 16.79057 \\
\hline 2A & 0.179791 & 5.230009 \\
\hline 2Ad & 0.233324 & 92.89895 \\
\hline 2As & 0.243755 & 162.733 \\
\hline 1B & 0.250728 & 236.7173 \\
\hline 2B & 0.246367 & 187.2569 \\
\hline 3B & 0.262564 & 447.1869 \\
\hline 4B & 0.27099 & 703.3438 \\
\hline 5B & 0.245026 & 174.2384 \\
\hline 6B & 0.282267 & 1289.362 \\
\hline 7B & 0.275885 & 915.0001 \\
\hline 12B & 0.239842 & 131.8709 \\
\hline 13B & 0.253205 & 270.4311 \\
\hline
\end{tabular}

The porosity and permeability normalization for A layer.

\section{Triagle Kriging}

\section{The ojectives and algorithm}

- Ojectives: Based on the porosity values of 03 wells: $1 \mathrm{~A}, 1 \mathrm{~B}, 4 \mathrm{~B}$, the porosity at $\mathrm{P}$ point is interpolated (the position of $\mathrm{P}$ point is chosen coincided with well 3B in which known values) (Figure 09).

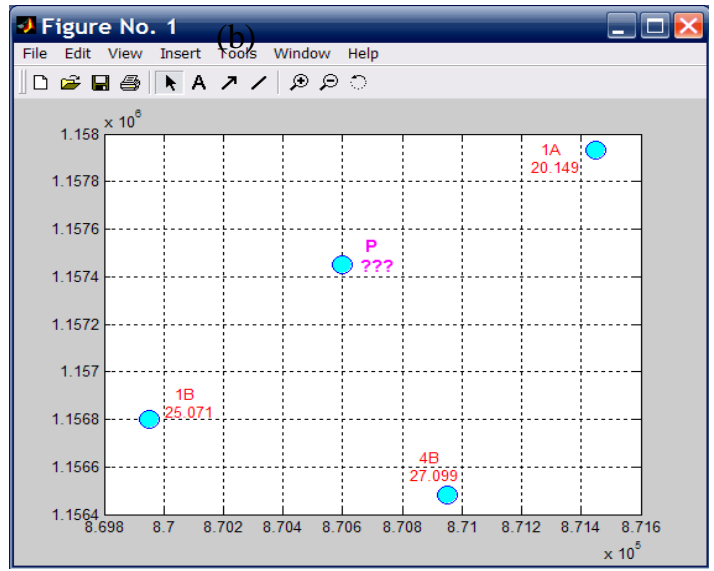

Figure 9. The position of 3 wells and interpolating points 


\section{- The algrorithm:}

The interpolation value at $\mathrm{P}$ point detrmined by equation [2]:

$$
\mathrm{Z} *(\mathrm{P})=\sum_{\alpha=1}^{3} \lambda_{\alpha} Z\left(u_{\alpha}\right)
$$

The $\lambda_{\alpha}$ calculated from equation series:

$$
\begin{aligned}
& \lambda_{1} \gamma\left(h_{11}\right)+\lambda_{2} \gamma\left(h_{12}\right)+\lambda_{3} \gamma\left(h_{13}\right)=\gamma\left(h_{1 P}\right) \\
& \lambda_{1} \gamma\left(h_{21}\right)+\lambda_{2} \gamma\left(h_{22}\right)+\lambda_{3} \gamma\left(h_{23}\right)=\gamma\left(h_{2 P}\right) \\
& \lambda_{1} \gamma\left(h_{31}\right)+\lambda_{2} \gamma\left(h_{32}\right)+\lambda_{3} \gamma\left(h_{33}\right)=\gamma\left(h_{3 P}\right)
\end{aligned}
$$

In such the condition satisfied:

$$
\lambda_{1}+\lambda_{2}+\lambda_{3}=1
$$

To assess the errors, the Lagrange would added Lagrange Multipliers:

$$
\begin{aligned}
& \lambda_{1} \gamma\left(h_{11}\right)+\lambda_{2} \gamma\left(h_{12}\right)+\lambda_{3} \gamma\left(h_{13}\right)+\lambda=\gamma\left(h_{1 P}\right) \\
& \lambda_{1} \gamma\left(h_{21}\right)+\lambda_{2} \gamma\left(h_{22}\right)+\lambda_{3} \gamma\left(h_{23}\right)+\lambda=\gamma\left(h_{2 P}\right) \\
& \lambda_{1} \gamma\left(h_{31}\right)+\lambda_{2} \gamma\left(h_{32}\right)+\lambda_{3} \gamma\left(h_{33}\right)+\lambda=\gamma\left(h_{3 P}\right) \\
& \lambda_{1}+\lambda_{2}+\lambda_{3}+0=1
\end{aligned}
$$

Transform in to matrix:

$$
\left[\begin{array}{cccc}
\gamma\left(h_{11}\right) & \gamma\left(h_{12}\right) & \gamma\left(h_{13}\right) & 1 \\
\gamma\left(h_{21}\right) & \gamma\left(h_{22}\right) & \gamma\left(h_{23}\right) & 1 \\
\gamma\left(h_{31}\right) & \gamma\left(h_{32}\right) & \gamma\left(h_{33}\right) & 1 \\
1 & 1 & 1 & 0
\end{array}\right] \bullet\left[\begin{array}{c}
\lambda_{1} \\
\lambda_{2} \\
\lambda_{3} \\
\lambda
\end{array}\right]=\left[\begin{array}{c}
\gamma\left(h_{1 P}\right) \\
\gamma\left(h_{2 P}\right) \\
\gamma\left(h_{3 P}\right) \\
1
\end{array}\right]
$$

$\mathrm{A} * \mathrm{~B}=\mathrm{C} \Rightarrow \mathrm{B}=\mathrm{C}^{*} \mathrm{~A}^{-1}=\mathrm{C} * \operatorname{inv}(\mathrm{A})$

The Variogram values calculated by formula (2) and absolute linear model (due to the number of data are restriction only 03 sets).

The B matrix calculated with the weighted results similarly, hence the value at point $\mathrm{P}$ determined here after:

$$
\mathrm{Z} *(\mathrm{P})=\lambda_{1} Z_{1}+\lambda_{2} Z_{2}+\lambda_{3} Z_{3}
$$

The square power varian:

$$
\mathrm{s}^{2}=\lambda_{1} \gamma\left(h_{1 p}\right)+\lambda_{2} \gamma\left(h_{2 p}\right)+\lambda_{3} \gamma\left(h_{3 p}\right)+\lambda
$$

The solution

\section{Porosity Kriging:}

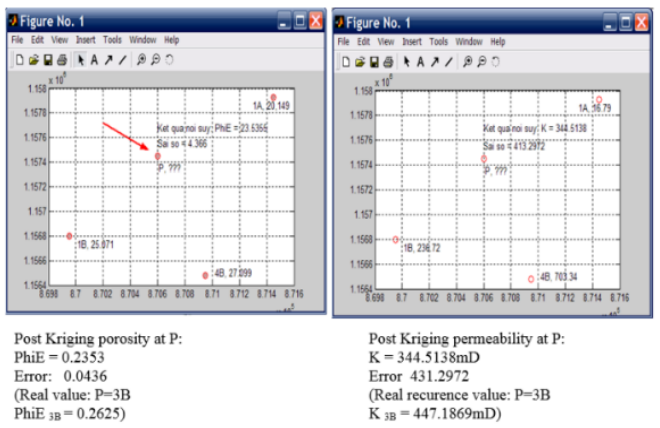

Build up the porosity and permeability distribution from 13 well data

Objectives and methods

a) The objectives: Applying the interpolating cell-Kriging in order to interpolate the value of all points in sphere of interpolation from data of 13 wells (Figure 10), particularly in A layer, lower Miocene reservoir, ST Xam oil field.

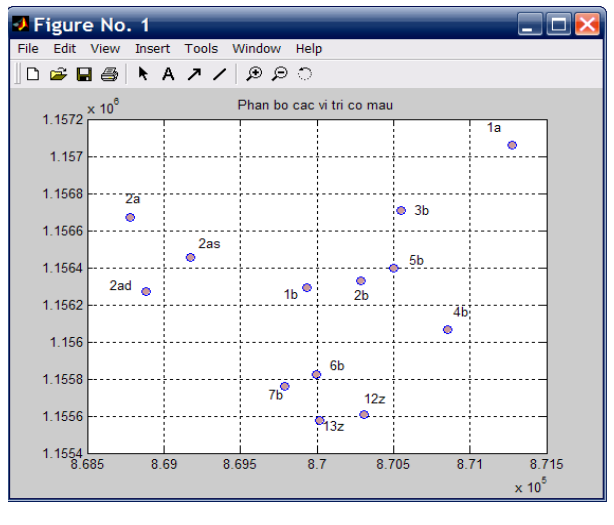

Figure 10: The distribution of 13 well samples

b) Methods: Based on interporating algorithm from three wells concerned in 4 item, the other points were interporated with much more data, the critical matters are applying meshgrid funtion in Matlab to create interpolating cell-Kriging instead of point interpolated.

Appropriating with 13 position, the algorithm divided cell system from $31 \times 31,61 \times 61$ to $121 \times 121$ (event higher if needed).

The appropriating syntax for $31 \times 31$ cell system here after:

\section{Trang 160}


$\mathrm{R}$

linspace $(868500,871500,31) \quad \% 868500: 100: 871500$, $\mathrm{xi}=100$

$\mathrm{Q}=$ linspace $(1155400,1157200,31)$;

$[\mathrm{Xg} 1, \mathrm{Xg} 2]=$ meshgrid $(\mathrm{R}, \mathrm{Q})$;

Following step is applied the reshape function to transfer the network co-ordinate to vector one, serving for calculation by equations of concerned algorithm (item 4.1).

The calculation results of Variogram with exposed on graph could not performe the present function of Variogram which appropriated with the porosity, therefor all models needed to used by applying the usual Variogram: Linear, Spherical, Exponential, Gaussian, as the supervision tools for experiment the Gaussian model (the results are presented in Figure 11) [3].

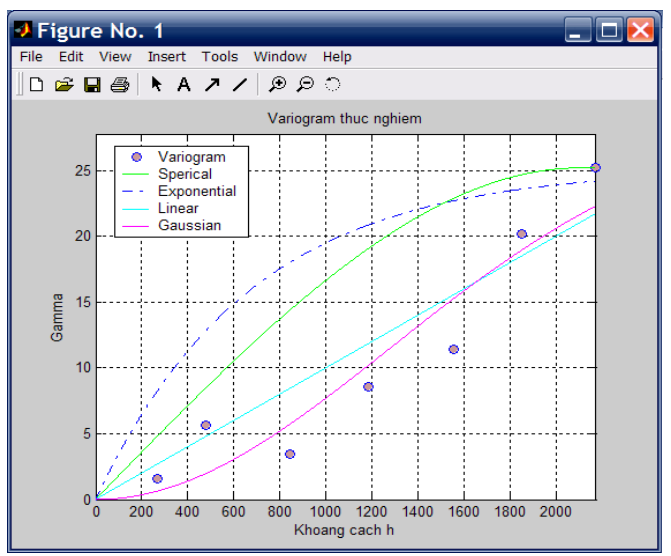

Figure 11: The experiment Variogram model

After Varigram models are determined with apropriation nugget, sill, and correlation intervals (in revision range), next step is Kriging for porosity in order to recur the permeability value. At last performe all values by interpolating cells and appropriative $\mathrm{X}$ and $\mathrm{X}$ co-ordinate.

\section{The porosity distribution model}

\section{a) Build up Variogram model}

The experiment Variogram is executed on distance couple one: $\mathrm{G}=0.5^{*}(\mathrm{Z} 1-\mathrm{Z} 2)^{\wedge} 2$;

The calculation results for all data couple are Variogram Fuzzi logic (Figure 12):

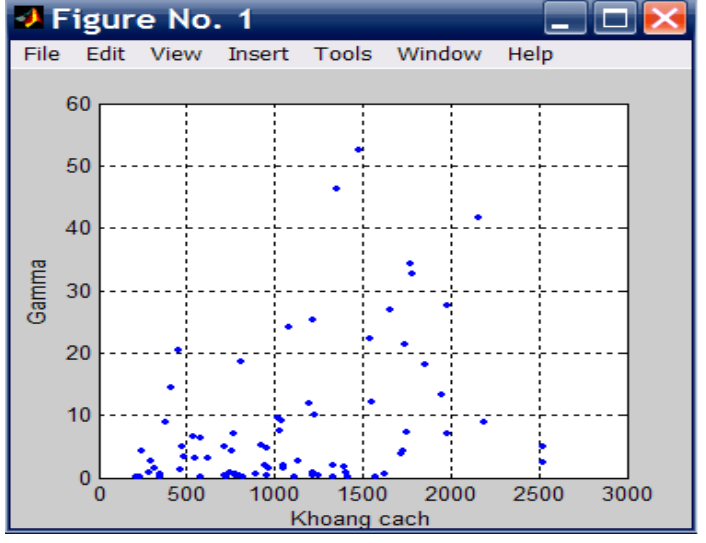

Figure 12: The Variogram Fuzzy logic

The lag distance is determined by equation = 345.825805317015 and the number of lag distances are 7 , the received results are experiment Variograms (Figure 11).

The appropriations with Variograms are 4 models: Linear, Spherical, Exponential and Gaussian types in which Gaussian is the selected choice due to most appropriation with performing graph.

\section{b) Kriging}

The meshgrid function is applied to generate interpolative grid $31 \times 31,61 \times 61$ and $121 \times 121$, after Kriging the received results are (Figure 13):

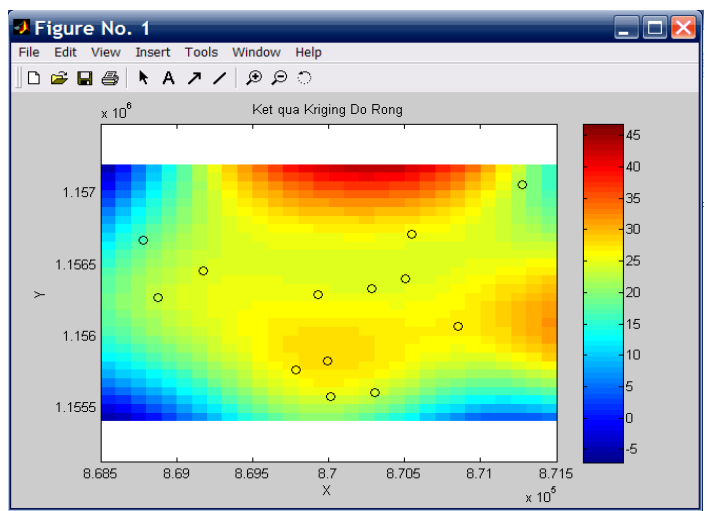

Figure 13: The porosity Kriging results for meshgrid $31 \times 31$

The square power varian of Kriging (Figure 14): 


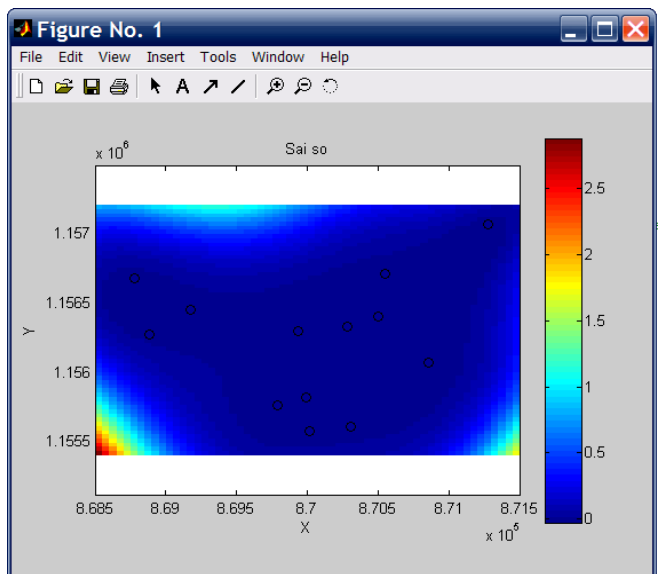

Figure 14: The square power varian of Kriging

The raw Kriging results supplied the porosity values smaller then 0 or too large (compared to sandstone formation), therefore its needed to correlate by adding cut-off value in to syntax in order to re-filter cellKriging results.

The porosity cut-off values are $5 \div 35 \%$ and $15 \div 32 \%$ applied for $61 \times 61$ cell grid and $121 \times 121$ cell grid respectively.

The over cut-off values assigned are Null area $(\mathrm{NaN})$, this technique could performed the Kriging range and the porosity distribution would much apparently in the case of bigger cell grids.

(The results of possible cut-off and core cut-off value presented in figure 15, 16 respectively).

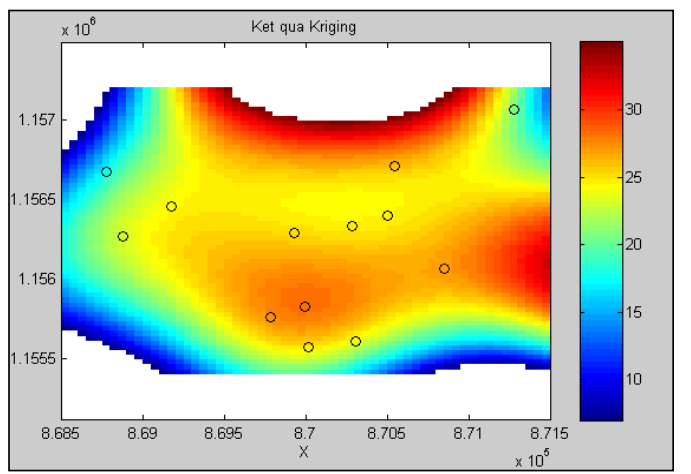

Figure 15: The porosity Kriging results after correlation of possible cut-off values $(61 \times 61$ grid $)$

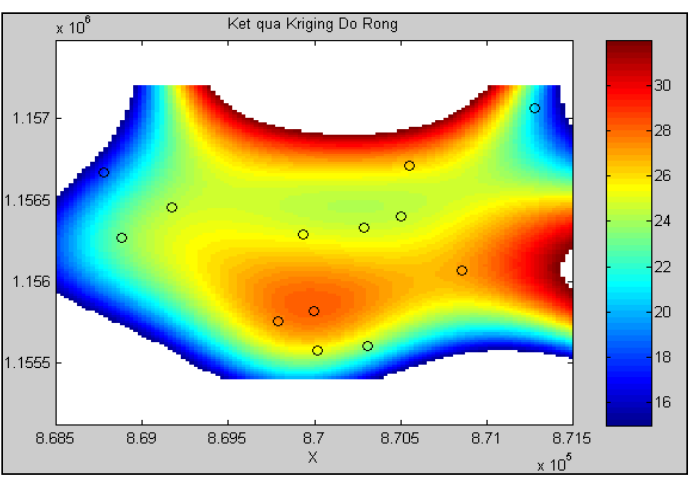

Figure 16: The porosity Kriging results after correlation of core cut-off values $(121 \times 121)$ grid)

The permeability distribution is able to generate by two methods:

- Recurring-Kriging: The primary permeability values are recurred from 13 wells and hence to conduct Kriging.

- $\quad$ Kriging - Recurring: The permeability is recurred from porosity Kriging.

Based on calculation results, the Recurring Kriging methods from input data recurrence were not acceptable, therefore the Variogram generation do not perform the standard model (the experiment fundamental also improve the porosity Variogram is Gaussian model). Hence the chosen method is Krigingrecurring.

In order to recur the permeability from porosity Kriging, the first step is determined the cut-off value of porosity by core analysis (Figure 17).

The cut-off value of porosity by core analysis:

if $Z g(k)<0.15 Z g(k)=0.15$; end

if $Z g(k)>0.32 \quad Z g(k)=0.32$; end

The recurring equation is:

$$
\begin{aligned}
& Z g(k)=\operatorname{sum}\left(E(1: n, 1) \cdot *_{z}\right) / 100 \\
& Z g(k)=10^{\wedge}(Z g(k) * 23.34086-3.477972) ;
\end{aligned}
$$

The permeability Kriging- recurring results are performed in Figure 17a (31 $\times 31$ cell grid) and $\mathbf{1 7 b}$ (611x61 cell grid).

This result error could not recurred from porosity Kriging errors, therefore the results will be compared

\section{Trang 162}


with permeability data which collected from core analysis (2A and $3 \mathrm{~A})$.

The Kriging from 03 wells: The interpolating point are chosen coincide with location of well 3B in order to experiment the Kriging technique and then assesment the results and error.

The interpolating porosity value is $23.53 \%$, the real value is $26.25 \%$, the error is $|0.2353-0.2625|=0.0272$ (smaller than Kriging 4.36\%), quite satisfaction with syntax point of view and acceptable; but the variance of porosity after Kriging fairly large (from $19.17 \%$ to $27.89 \%$ ) hence the certainty of such methods not surely hight.

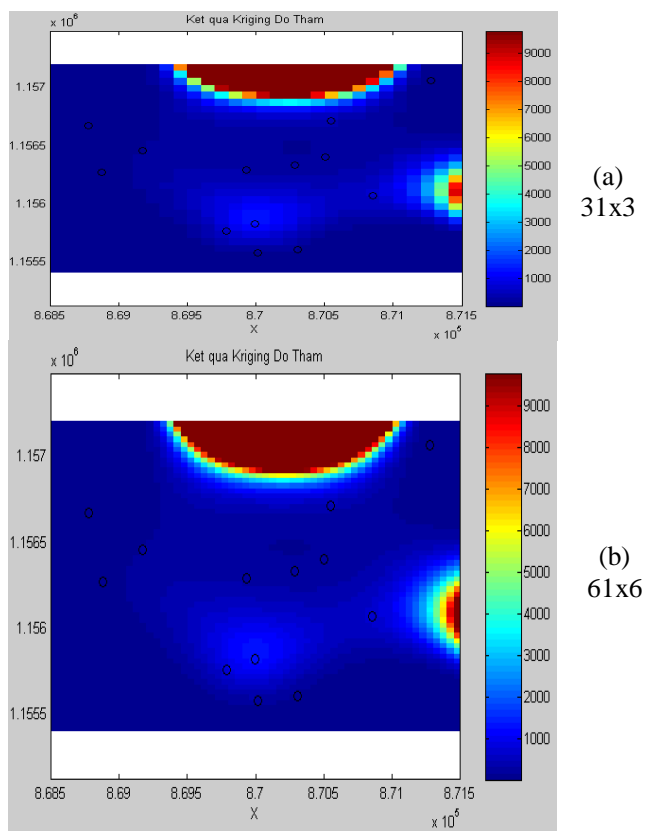

Figure 17: The permeability Kriging-recurring results

\section{Analysing and assesing the certainty of model}

The interpolating permeability value is 344.5138 $\mathrm{mD}$, the real value is $447 \mathrm{mD}$, therefore the error is acceptable, however the Kriging error is $431.292 \mathrm{mD}$, higher than the interpolating value, hence the Kriging results are unreliable. This situation coud be able explanted by two reasons:

- The permeability value recurred from the porosity (before Kriging) supplied the data with great error, due to event the variance of porosity is minor but lead to make the variance of permeability quite significant (Figure 08).

- In the case the number of data is few, the linear Variogram will make great error.

\section{Conclusions and recommendation}

The results of porosity distribution model: With the amount of maximum data (13 wells), the post correlation results of both potential cut-off values and core cut-off values are reasonable. The error of model are minor and distributed apropriately with Kriging range. However the results are numerous correlation. The parameters of Variogram are not performe the expected approach. The data should much collected in order to accuratimize the variogram form.

The results of permeability distribution model: The experiment results are collected just from 03 points, therefore the ultimate solution is recurred porosity from porosity Kriging results. But this method do not allow asses error of results due to not be able to recurring the errors.

The ignorance of effects by depth difference of data and lack to assign the porosity and permeability in to appropriation facies are limitation of the method.

The unsolved matter need to modelized by specific software (such as Petrel, RMS) and experiment in order to eliminate this shortcomings. 


\section{Áp dụng thuật toán Kriging trên môi trường Matlab nội suy giá trị độ rỗng và độ thấm của tầng chứa Miocen hạ, mỏ Sư Tử Xám}

- Trương Quốc Thanh

- Thái Bá Ngọc

- Nguyễn Xuân Khá

- Nguyễn Xuân Huy

- Đậu Văn Ngọ

- Trần Văn Xuân

- Nguyễn Đức Đông

- Nguyễn Văn Tuân

Trường Đại học Bách khoa, ĐHQG-HCM - tvxuan@hcmut.edu.vn

\section{TÓM TÁT:}

Bài báo trình bày phương thức áp dụng kỹ thuật Kriging trên môi trường Matlab để nội suy giá trị của các điểm trong phạm vi nội suy từ những giá trị độ rỗng thu được ở 13 giếng của tầng chứa Miocen hạ, mỏ Sư Tử Xám. Chức năng meshgrids MATLAB được ứng dụng để tạo ra các tế bào nội suy (cell-Kriging) thay vì suy đoán điểm rời rạc. Sau khi mô hình Variogram với giá trị nugget và ngưỡng tương quan (trong phạm vi) đã được chọn, bước tiếp theo là từ giá trị độ rỗng Kriging tiến hành hồi quy giá trị độ thấm. Cuối cùng, hiển thị các giá trị trong tọa độ hệ tọa độ $X, Y$, tương ứng. Từ dữ liệu đầu vào nhiệm vụ đầu tiên là phân tích thiết lập tương quan, chọn các thông số cần thiết và loại bỏ các dũ liệu vô ích, đánh giá phạm vi áp dụng của từng loại dữ liệu. Sau đó kết hợp các tài

Từ khóa: Kriging, Co-Kriging, MATLAB, Variogram, nội suy, thuật toán, mô hình độ rỗng và thấm, vòng lăp.

\section{TÀI LIỆU THAM KHẢO}

[1]. Oil initial in place reserves estimation report (2005), Cuu Long joint venture Company.

[2]. Caers, J. (2005). Petroleum Geostatistics, Society of Petroleum Engineers.

[3]. Chambers, R.L. (2003). Geostatistical Reservoir Modeling: Outcrop to Simulator, Quantitative Geosciences LLP (QGSI). Presentations. liệu với kết quả minh giải địa vật lý giếng khoan xác định tầng và lớp chứa từ đó tiến hành lọc các dũ liệu trung bình tương ứng. Trên cơ sở trị trung bình của các giá trị đã được lựa chọn tương ứng, từ mỗi giếng tính toán kết quả của mô hình Variogram thực nghiệm cho từng phân lớp, làm cơ sở cho giải ma trận Kriging. Công việc cuối cùng là tính toán sai số và đánh giá độ tin cậy của kết quả Kriging. Sai số của mô hình độ rỗng nhỏ và phân bố tiệm cận với giới hạn Kriging. Tuy nhiên, kết quả tính chịu ảnh hưởng của rất nhiều mối tương quan. Các kết quả thí nghiệm xác định độ thấm chỉ thu thập được từ 03 giếng khoan, do đó giải pháp xác định rỗng - thấm vòng lặp tư kết quả Kriging độ rỗng là cần được áp dụng.

[4]. Martinezs, (2002). Computational Statistics Handbook with MATLAB, Chapman \& Hall/CRC.

[5]. Mike Christie, Vasily Demyanov, Demet Erbas (2006). Uncertainty quantification for porous media flows, Journal of Computational Physics 217.

\section{Trang 164}


[6]. M.A. Christie, J. Glimm, J.W. Grove, D.M. Higdon, D.H. Sharp, M.M. Wood-Schultz, Error analysis and simulations of complex phenomena, Los Alamos Sci. 29 (2005) 6-25.
[7]. J.S. Archer, C.G. Wall (1986), Petroleum Engineering: Principles and Practice, Kluwer Academic Publishers 